\section{US is accused of jeopardising HIV prevention in Uganda}

Ozge Tuncalp Connecticut

The United Nations' special envoy for HIV and AIDS in Africa, Stephen Lewis, has accused the United States of bowing to pressure from religious groups and promoting abstinence only programmes in Uganda to prevent HIV infection.

Uganda has been one of Africa's success stories in terms of HIV prevention. The rate of transmission of HIV declined from $15 \%$ a year in 1991 to $5 \%$ in 2001. One of the generally accepted reasons for the success has been President Yoweri Museveni's acknowledgment of the epidemic as a serious problem. Unlike many other African leaders President Museveni has called for a nationwide fight against HIV and AIDS and has allowed non-governmental organisations to embrace the "ABC" approach (abstinence, be faithful, condoms) to reduce infection rates.

However, Mr Lewis's remarks, made at a press conference at the end of August, have raised concerns about recent changes to prevention programmes in Uganda.

Mr Lewis said that the US government had been "acting under the influence of the religious right in the US by running the multibillion dollar campaign emphasising abstinence." He also raised concerns about the reduced availability of condoms in the country and a tripling in their price.

Mark Dybul, deputy US global AIDS coordinator, denied the accusations. "The statements that I have heard are completely untrue and completely mischaracterise effective prevention programmes," he said.

African countries such as Uganda rely heavily on foreign aid to support their nationwide projects, including their HIV and AIDS prevention programmes. Over the past two years $\$ 200 \mathrm{~m}$ (£113m; €166m) from the US president's emergency plan for AIDS relief was channelled to Uganda to support the prevention programmes.

Although the president's pro-

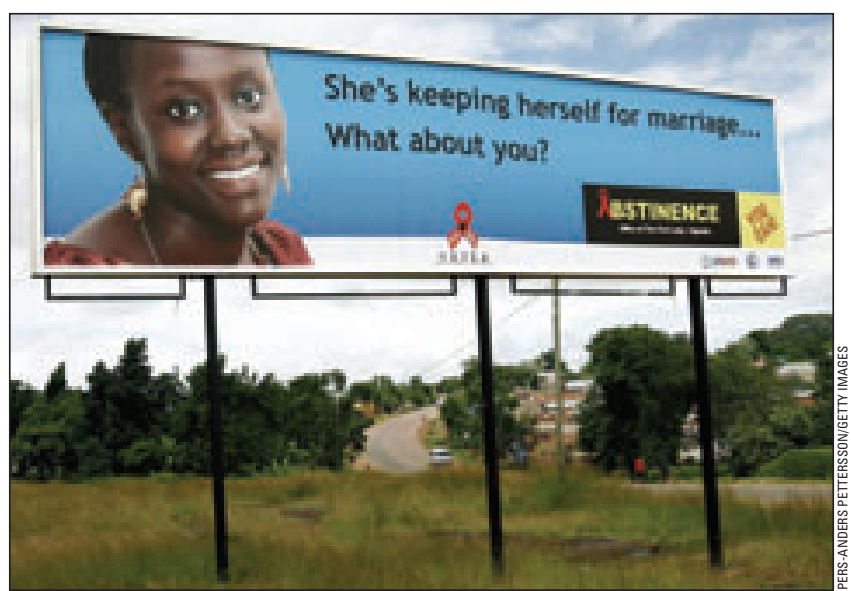

Advertisements promoting abstinence only behaviour to prevent HIV infection are filling billboards across the country

gramme was widely welcomed by charities and aid organisations, it has also been a cause of debate for its explicit support of abstinence only prevention projects (BMJ 2004;329:192).

The Museveni government denies any change in policy. However, a recently introduced regulation forbids any national or international non-governmental organisation distributing condoms in high schools during HIV and AIDS education classes, in which hundreds of young adults, many of whom are sexually active, can be reached.

Advertisements promoting abstinence only behaviour are filling billboards across the country. Moves such as "calling for a census of virgins in the country," led by the president's wife, an evangelical Christian and opponent of condom use, are also abundant.

Stephen Lewis' remarks are at www. genderhealth.org/uganda.php

\section{US state rejects federal funding for abstinence only sex education}

Janice Hopkins Tanne New York

The liberal northeastern state of Maine has decided not to accept federal funding for school sex education because the federal programme requires teachers to promote abstinence until marriage and mutual faithfulness afterwards rather than provide comprehensive sex education. California and Pennsylvania have also rejected funding for abstinence only sex education.

The American Civil Liberties Union has launched a national campaign to urge officials in 18 states to reject abstinence until marriage education. It said many abstinence only programmes contained inaccurate information.

Maine turned down $\$ 165000$ (£93 000; €137 000), nearly a third of its "family life education" budget for school sex education.
Dora Anne Mills, Maine's director of public health, said that rules about what states can tell young people-if the states wanted federal funding-had become more restrictive since the funding law was passed in 1996.

The rules to be taught about sexual abstinence outside marriage are:

- Abstinence provides social, psychological, and health gains;

- Abstinence is the expected standard for all school age children;

- Abstinence is the only certain way to avoid pregnancy out of wedlock, sexually transmitted diseases, and associated health problems;

- Mutually faithful monogamy in the context of marriage is the expected standard of human sexual activity;

- Sexual activity outside marriage is likely to have harmful psychological and physical effects; and

- Bearing a child out of wedlock is likely to have harmful consequences for the child, its parents, and society.

Lessons must also teach young people how they can reject sexual advances and how consuming alcohol and drugs increases their vulnerability They must also teach the importance of "achieving self sufficiency" before engaging in sexual activity.

When the funding law was first passed, Dr Mills said, states could use federal funds to focus on just some of the main points. Maine prepared television advertisements urging teenagers to postpone sexual activity and to achieve self sufficiency before engaging in sex. However, she said states are now required to emphasise all eight points equally to get federal funds.

"This completely violates our comprehensive approach to family life education," she said. Maine's "family life education" programme dates back 20 years and has been endorsed by Democratic, Republican, and independent governors and by the state legislature. The programme is taught from kindergarten through to the 12th grade (the last year of high school) at appropriate levels. It includes learning about body parts, about puberty, and refusal skills.

When the programme began, Maine had one of the highest rates of pregnancy among white teenagers in the nation. Since then it has seen the steepest decline in numbers of teenage pregnancies in the country: from 3000 in 1985 to 1600 at present. Maine has also seen a steep decline in abortions.

"This has been a tremendous public health success," Dr Mills said. She called it "quite shameful" that funds for the comprehensive approach had diminished." 